JONEs, D. A. 1972. Cyanogenic clycosides and their function. In Phytochemical Ecology (ed.

J. B. Harborne), pp. 103-124. Academic Press, London.

Jonzs, D. A. 1973. Coevolution and cyanogenesis. Proc. Symp. Syst. Assn., in press.

DE WAal, D. 1942. Het Cyanophore Karakter van Witte Klaver, Trifolium repens $\mathrm{L}$. Thesis,

H. Veenman en Zonen N.V., Wageningen.

whrTMan, R. J. 1973. Herbivore feeding and cyanogenesis in Trifolium repens L. Heredity, in press.

\title{
MAINTENANCE OF MALE STERILITY IN PLANT POPULATIONS II. HETEROTIC MODELS
}

\author{
TAI-YING HO* and M. D. ROSS $\dagger$ \\ Department of Biology, Dalhousie University, Halifax, Nova Scotia, Canada
}

Received 12.ii.73

\section{Summary}

Gynodioecious populations contain male-sterile and hermaphrodite individuals, and gynodioecy has been interpreted as an outbreeding system.

Male-steriles require a mechanism for their maintenance in gynodioecious populations.

A theoretical study showed that for given values of heterozygote advantage, equilibrium proportions of male-steriles depended upon genetic control of the male sterility. These proportions were greatest where control was digenic with complementary gene action; lower where control was through a monogenic recessive; lower still where control was digenic with recessive suppressor gene action; and least when control was through duplicate genes.

With digenic inheritance, linkage between the sex-control genes was generally associated with reduced proportions of male-steriles.

\section{INTRODUCTION}

MaNY species of flowering plants comprise, in addition to hermaphrodites, considerable proportions of male-sterile individuals. Such species are called gynodioecious, and gynodioecy has been interpreted as an outbreeding mechanism (Mather, 1940). Because of their sterility with respect to hermaphrodites, male-steriles would be lost from a population containing both forms, unless they had some mechanism for their maintenance. In natural populations of gynodioecious plants male-steriles may be maintained by their greater fruit set compared to hermaphrodites (Burrows, 1960) or by the lethality or partial lethality of some hermaphrodite genotypes (Lewis and Crowe, 1956). Theoretical studies of the effects of increased seed production by the male-steriles on their maintenance in gynodioecious populations were made by Lewis (1941), and by Ross and Shaw (1971). These authors found that male-steriles were only maintained if they produced a minimum of somewhat over twice as many seeds as hermaphrodites. Heterozygote advantage for fitness might also constitute a mechanism for maintenance of male-steriles. For example, with monogenic recessive male sterility and heterozygote advantage, male-steriles could be maintained because of recombination among heterozygous hermaphrodites. Jain (1961) studied

* Present address: Department of Pathology, University of Toronto, Toronto 2, Canada.

$\dagger$ Present address: Grasslands Division, D.S.I.R., Palmerston North, New Zealand. 
models of inbreeding populations in which a recessive male-sterility gene showed heterozygote advantage, and where male-sterile plants were more likely to be outcrossed than were male-fertiles. He showed that considerable heterozygosity could be maintained under some conditions. Jain and Suneson (1964) found that a recessive male-sterility gene, which had been introduced into barley populations, decreased in frequency but was not eliminated during many generations. Heterozygote advantage at the malesterility locus may have been partly responsible for the persistence of the gene. This note reports studies of the relationship between heterozygote advantage for fitness at loci causing male sterility, and the proportions of malesteriles maintained.

\section{Methods}

The results were obtained by computer simulation of a model given by Shaw (1957), and modified for hermaphroditic organisms by Ross and Shaw (1971). The relative numbers of offspring left by given matings were calculated by the second method of Ross and Shaw (1971) and heterozygote advantage was then superimposed upon this basic fitness model. Under digenic inheritance fitness models were symmetrical, since the fitness of the heterozygote at the first locus was assumed to equal that at the second locus. In addition fitness interactions between loci were taken as multiplicative in epistatic models, and additive in the non-epistatic models (Falconer, 1960).

The following cases were studied $\left(\mathrm{F}_{2}\right.$ ratios in parentheses, with hermaphrodites placed first): monogenic recessive male-sterile (3:1); digenic, with the double recessive male-sterile (15:1); digenic, complementary genes (9:7); digenic, recessive suppressor (13:3).

Several initial genotype frequencies were used to obtain each result, and all initial frequencies appeared to converge to a single frequency of malesteriles for each set of conditions. The results are given after 500 generations, and are rounded off from nine figures. Most results were at equilibrium, but some showed changes in the last two or three figures at 500 generations, suggesting that equilibrium had not quite been attained, or that accumulated rounding-off errors had caused fluctuations.

\section{Results}

The effects of several factors on the equilibrium proportions of malesteriles were studied. In addition to heterozygote advantage, these factors included monogenic or digenic control of male sterility, and linkage. A selection of these results is given here.

Fig. 1 and table 1 give the frequencies of male-steriles as a function of fitness of the heterozygote under monogenic recessive inheritance of male sterility, and under digenic inheritance with three modes of gene interaction. In addition, for digenic models, fig. 1 shows the effects of epistatic and nonepistatic interactions for fitness. From the figure it is clear that mode of inheritance of male sterility has a marked influence on the proportions of male-steriles kept in the population for given fitness values of the heterozygotes. The greatest proportions of male-steriles are maintained under digenic inheritance of male sterility with complementary gene interaction, 
and fewest male-steriles are maintained where genetic control is via duplicate genes. In all cases epistatic fitness interactions are associated with greater equilibrium proportions of male-steriles than are non-epistatic interactions. Epistatic fitness interactions have the greatest effect where control of male sterility is through complementary genes, and have least effect when control is by duplicate genes.

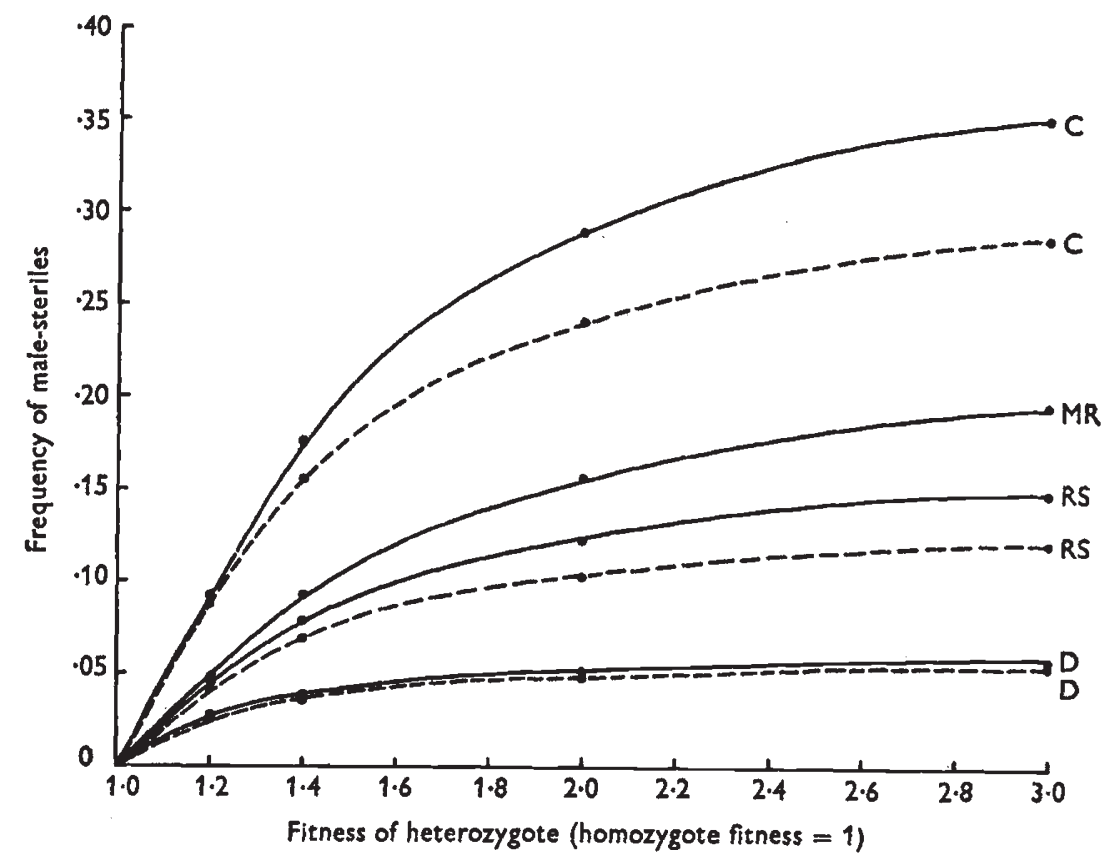

Frg. 1.-Effect of heterozygote advantage on proportions of male-steriles under four modes of inheritance of male sterility. Continuous lines are used for epistatic, and broken lines for non-epistatic fitness interactions. $\mathrm{C}=$ complementary genes; $\mathrm{MR}=$ monogenic recessive; $\mathrm{RS}=$ recessive suppressor; $\mathrm{D}=$ duplicate genes.

Linkage between the sex-controlling genes caused reductions in proportions of male-steriles maintained for given heterosis values under the epistatic models, except for inheritance through complementary genes with a low degree of heterozygote advantage, where linkage was associated with a slight increase in male-steriles (table 1). In general, the tighter the linkage, the lower the proportion of male-steriles. The effect of tight linkage was least where control of male-sterility was through complementary genes, and greatest where control was through duplicate genes.

Increased values of heterozygote advantage were associated with increased proportions of male-steriles, except where there was tight linkage with inheritance through recessive suppressor or duplicate genes. In these cases there was respectively a slight increase followed by a decline, and a steady decline in proportions of male-steriles, with increasing values of heterozygote advantage.

\section{Discussion}

We have seen that different modes of inheritance of male-sterility are reflected in differences in the proportions of male-steriles maintained for 
given values of heterozygote advantage. It is therefore possible that the modes of inheritance of male-sterility in nature may be relevant to the system of maintenance of the male-steriles. In contrast to this situation, models where male-steriles were maintained by increased relative seed set showed no effect of mode of nuclear inheritance on proportions of male-steriles maintained (Ross and Shaw, 1971).

\section{TABLE 1}

Effects of linkage for sex-control genes on proportions of male-steriles maintained by heterozygote advantage with epistatic fitness interactions, together with proportions of male-steriles maintained under monogenic inheritance

\begin{tabular}{|c|c|c|c|c|c|c|c|c|c|c|}
\hline \multirow{3}{*}{$\begin{array}{c}\text { Degree of } \\
\text { heterozygote } \\
\text { advantage } \\
\text { (homozygote }=1 \text { ) }\end{array}$} & \multicolumn{10}{|c|}{ Proportions of male-steriles } \\
\hline & \multirow{2}{*}{$\begin{array}{l}\text { Monogenic } \\
\text { recessive }\end{array}$} & \multicolumn{3}{|c|}{$\begin{array}{l}\text { Complementary genes } \\
\text { Recombination values }\end{array}$} & \multicolumn{3}{|c|}{$\begin{array}{l}\text { Recessive suppressor } \\
\text { Recombination values }\end{array}$} & \multicolumn{3}{|c|}{$\begin{array}{c}\text { Duplicate genes } \\
\text { Recombination values }\end{array}$} \\
\hline & & 0.5 & 0.2 & 0.01 & & 0.2 & 0.01 & 0.5 & $0 \cdot 2$ & 0.01 \\
\hline $\begin{array}{l}1 \cdot 2 \\
1 \cdot 4 \\
2 \cdot 0 \\
3 \cdot 0\end{array}$ & $\begin{array}{l}0 \cdot 0483 \\
0 \cdot 0919 \\
0 \cdot 1561 \\
0 \cdot 1948\end{array}$ & $\begin{array}{l}0.0919 \\
0.1757 \\
0.2885 \\
0.3499\end{array}$ & $\begin{array}{l}0.0942 \\
0.1750 \\
0.2863 \\
0.3487\end{array}$ & $\begin{array}{l}0 \cdot 1019 \\
0 \cdot 1596 \\
0 \cdot 2183 \\
0 \cdot 2413\end{array}$ & $\begin{array}{l}0 \cdot 0466 \\
0 \cdot 0787 \\
0 \cdot 1223 \\
0 \cdot 1477\end{array}$ & $\begin{array}{l}0.0457 \\
0.0760 \\
0.1185 \\
0.1446\end{array}$ & $\begin{array}{l}0.0097 \\
0.0109 \\
0.0099 \\
0.0082\end{array}$ & $\begin{array}{l}0.0285 \\
0 \cdot 0394 \\
0 \cdot 0519 \\
0.0579\end{array}$ & $\begin{array}{l}0.0263 \\
0.0364 \\
0.0485 \\
0.0547\end{array}$ & $\begin{array}{l}0.0051 \\
0 \cdot 0027 \\
0 \cdot 0004 \\
0 \cdot 0001\end{array}$ \\
\hline
\end{tabular}

From 2 or 3 up to 50 or more per cent. male-steriles have been reported in otherwise hermaphrodite populations (Knuth, 1906-09). Although low frequencies of male-steriles may be maintained by heterozygote advantage under any of the four systems of inheritance considered here, it seems that other methods (e.g. lethality) may prove more effective at maintaining high proportions of male-steriles (e.g. 30 per cent. or more). For example, we have seen that in the recessive suppressor system under our assumptions, such high proportions of male-steriles are not easily maintained by heterozygote advantage alone, and it is interesting to see that in Origanum vulgare, which has recessive suppressor inheritance, and where there are 30-50 per cent. male-steriles, the male-steriles seem to be maintained by partial or complete lethality of some homozygotes, together with differential seed set and high mutation rate (Lewis and Crowe, 1956; Jain, 1968).

Acknowledgments.-We thank $\mathrm{Dr} \mathrm{R}$. F. Shaw for generously allowing the use of a computer programme developed by him, Mr A. P. Smith for modifying the programme to allow the study of linkage, and Dr D. G. Lloyd for commenting on the manuscript. We thank Dalhousie University Faculty of Graduate Studies for financial support. The data are contained in a thesis of T.-Y. Ho submitted to Dalhousie University in partial fulfilment of the requirements for an M.Sc. degree.

\section{REFERENCES}

BURrows, c. J. 1960. Studies in Pimelea. I. The breeding system. Trans. Royal Soc. New Zealand, 88, 29-45.

FALCONER, D. s. 1960. Introduction to Quantitative Genetics. Oliver and Boyd, Edinburgh and London.

JAIN, s. . . 1961. On the possible adaptive significance of male sterility in predominantly inbreeding populations. Genetics, 46, 1237-1240.

JaIN, s. x. 1968. Gynodioecy in Origanum vulgare: computer simulation of a model. Nature, $217,764-765$.

JAN, s. K., AND sUNeson, c. A. 1964. Population studies in predominantly self-pollinated species. VII. Survival of a male-sterility gene in relation to heterozygosis in barley populations. Genetics, 50, 905-913. 
kNuTH, P. 1906-09. Handbook of Flower Pollination. Clarendon Press, Oxford.

LEWIs, D. 1941. Male sterility in natural populations of hermaphrodite plants. New Phytol., 40, 56-63.

LEWIS, D., AND GROWE, L. K. 1956. The genetics and evolution of gynodioecy. Evolution, $10,115-125$.

MATHER, K. 1940. Outbreeding and separation of the sexes. Nature, 145, 484-486.

ROSs, M. D., AND SHAW, R. F. 1971. Maintenance of male sterility in plant populations. Heredity, 26, 1-8.

sHAW, R. F. 1957. The theoretical genetics of the sex ratio. Genetics, 43, 149-163. 